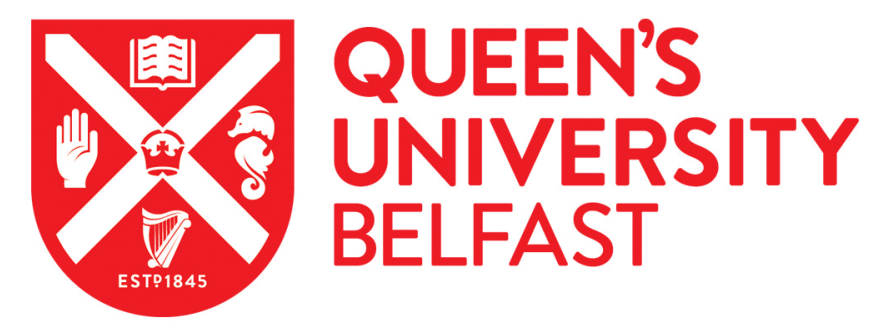

\title{
Interception of residual nitrate from a calcareous alluvial soil profile on the North China Plain by deep-rooted crops: a $15 \mathrm{~N}$ tracer study
}

Ju, X. T., Gao, Q., Christie, P., \& Zhang, F. S. (2007). Interception of residual nitrate from a calcareous alluvial soil profile on the North China Plain by deep-rooted crops: a $15 \mathrm{~N}$ tracer study. Environmental Pollution, 146(2), 534-542. https://doi.org/10.1016/j.envpol.2006.07.014

Published in:

Environmental Pollution

Queen's University Belfast - Research Portal:

Link to publication record in Queen's University Belfast Research Portal

\section{General rights}

Copyright for the publications made accessible via the Queen's University Belfast Research Portal is retained by the author(s) and / or other copyright owners and it is a condition of accessing these publications that users recognise and abide by the legal requirements associated with these rights.

Take down policy

The Research Portal is Queen's institutional repository that provides access to Queen's research output. Every effort has been made to ensure that content in the Research Portal does not infringe any person's rights, or applicable UK laws. If you discover content in the Research Portal that you believe breaches copyright or violates any law, please contact openaccess@qub.ac.uk. 


\title{
Interception of residual nitrate from a calcareous alluvial soil profile on the North China Plain by deep-rooted crops: A ${ }^{15} \mathrm{~N}$ tracer study
}

\author{
X.T. Ju ${ }^{\text {a,* }}$, Q. Gao ${ }^{\text {a,b }}$, P. Christie ${ }^{\text {a,c }}$, F.S. Zhang ${ }^{\text {a }}$ \\ ${ }^{a}$ Key Laboratory of Plant-Soil Interactions, Ministry of Education, College of Agricultural Resources and Environmental Sciences, \\ China Agricultural University, 2 Yuan Ming Yuan West Road, Hai Dian District, Beijing 100094, China \\ ${ }^{\mathrm{b}}$ College of Agricultural Resources and Environmental Sciences, Jilin Agricultural University, Changchun 130118, China \\ ${ }^{\mathrm{c}}$ Agricultural and Environmental Science Department, Queen's University Belfast, Belfast BT9 5PX, UK
}

Received 5 April 2006; received in revised form 28 July 2006; accepted 30 July 2006

Deep-rooted crops have a greater capacity than shallow-rooted crops to intercept residual nitrate from the subsoil and restrict its movement down to the shallow groundwater.

\begin{abstract}
${ }^{15} \mathrm{~N}$-labeled nitrate was injected into different depths of an alluvial calcareous soil profile on the North China Plain. Subsequent movement of $\mathrm{NO}_{3}^{-}-\mathrm{N}$ and its recovery by deep-rooted maize (Zea mays L.) and shallow-rooted eggplant (Solanum melongena L.) were studied. Under conventional water and nutrient management the mean recoveries of ${ }^{15} \mathrm{~N}$-labeled nitrate from $\mathrm{K}^{15} \mathrm{NO}_{3}$ injected at depths 15 , 45 , and $75 \mathrm{~cm}$ were $22.4,13.8$, and $7.8 \%$ by maize and $7.9,4.9$, and $2.7 \%$ by eggplant. The recovery rate by maize at each soil depth was significantly higher than by eggplant. The deeper the injection of nitrate the smaller the distance of its downward movement and this corresponded with the movement of soil water during crop growth. Deeper rooting crops with high root length density and high water consumption may therefore be grown to utilize high concentrations of residual nitrate in the subsoil from previous intensive cropping and to protect the environment.
\end{abstract}

(c) 2006 Elsevier Ltd. All rights reserved.

Keywords: Eutrophication; Eggplant; Groundwater; Leaching; Maize; Root morphology

\section{Introduction}

Large amounts of mineral nitrogen $(\mathrm{N})$, mostly in the form of nitrate, have been found to accumulate at various depths in the soil profile after crop harvest following excessive application of $\mathrm{N}$ fertilizers and manures in intensively managed crop production systems (Roth and Fox, 1990; Angle et al., 1993; Ju et al., 2004). Nitrate has a high potential either to leach downwards to the subsoil and eventually to groundwater or to denitrify to produce $\mathrm{N}_{2} \mathrm{O}$, a greenhouse gas that can be emitted to the atmosphere.

\footnotetext{
* Corresponding author. Tel.: +86106273 3459; fax: +861062731016. E-mail address: juxt@cau.edu.cn (X.T. Ju).
}

High intensity of cultivation (e.g. two cereal crops or up to four vegetable crops per year) and excessive application of $\mathrm{N}$ fertilizers or manures to each crop on the North China Plain mean that successive crops cannot efficiently utilize the residual nitrate that exists in the soil profile, leading to progressively increasing accumulation in the soil profile and subsequent leaching. According to our measurements of soil nitrate in 47 winter wheat fields after harvest, in 56 vegetable greenhouses after harvest, and in 34 apple orchards after harvest in Huimin county, Shandong province in 2003, nitrate accumulation in the top $90 \mathrm{~cm}$ of the soil profile was $52-609,270-5038$, and $32-2406 \mathrm{~kg} \mathrm{~N} \mathrm{ha}^{-1}$, respectively. The corresponding ranges of values at $90-$ $180 \mathrm{~cm}$ depth were 224-3273, 68-1047, and 228$2430 \mathrm{~kg} \mathrm{~N} \mathrm{ha}^{-1}$. The amounts of nitrate in the $0-90$ and 
90-180 cm depth zones in vegetable greenhouses were significantly higher than in the other two cropping systems (Ju et al., 2006).

Five pathways of residual nitrate in the soil profile have been identified. These are uptake by succeeding crops, leaching to the deep subsoil or shallow groundwater under intensive rainfall or irrigation (Ju et al., 2006), transfer to the upper soil horizons with upward soil water movement during periods of drought (Boswell and Anderson, 1964), denitrification to $\mathrm{N}_{2}$ or $\mathrm{N}_{2} \mathrm{O}$ under favorable conditions (Aulakh et al., 1992), and fixation by soil microorganism (Recous et al., 1990). The Nmin method for $\mathrm{N}$ fertilizer recommendations assumes that the availability to crops of residual $\mathrm{NO}_{3}^{-}-\mathrm{N}$ in the root zone (to about $100 \mathrm{~cm}$ depth) is equal to that of applied $\mathrm{N}$ fertilizer (Chen, 2003). However, plant root systems must develop first in order to take up the residual nitrate located at different soil depths. This implies that crops can utilize $\mathrm{NO}_{3}^{-}-\mathrm{N}$ from only certain soil layers at any particular growth stage. Numerous studies have shown crop recovery of residual ${ }^{15} \mathrm{~N}$ applied to previous crops but have not identified the recovery rates at different depths in the soil profile (Strong et al., 1996; Zhu, 1997; Jensen et al., 1997; Glendining et al., 2001). Rowe et al. (2001) developed ${ }^{15} \mathrm{~N}$ depth placement procedures to test and calculate recovery of nitrate from deep subsoils by plants. Menezes et al. (1997) investigated the recovery of subsoil nitrate by injecting $\mathrm{K}^{15} \mathrm{NO}_{3}$ solution with $60 \%{ }^{15} \mathrm{~N}$ abundance at a rate of $50 \mathrm{~kg} \mathrm{~N}^{-1}$ into a Kandiudult soil in the southeastern USA at a depth of $100 \mathrm{~cm}$. They found that the recovery of ${ }^{15} \mathrm{~N}$-labeled nitrate from that depth by pearl millet (Pennisetum glaucum (L.) R. Br.) was $14.7 \%$. Huang et al. (1996) used this technique to investigate the relative recoveries of deep point-injected soil ${ }^{15} \mathrm{~N}$ by switchgrass (Panicum virgatum L.), alfalfa (Medicago sativa L.) and maize, and found that the amounts of $\mathrm{N}$ taken up were 20,8 and $1 \mathrm{~kg} \mathrm{ha}^{-1}$, respectively. The studies described above have shown the recovery of ${ }^{15} \mathrm{~N}$-labeled nitrate at different soil depths by crops growing in soils with low background concentrations of residual nitrate in the soil profile. However, the movement of ${ }^{15} \mathrm{~N}$-labeled nitrate injected at different depths of the soil profile, including the subsoil, and its recovery by crops under conditions characteristic of the North China Plain remain to be investigated.

Residual nitrate is transported with soil water movement in the soil profile and most is concentrated in the topsoil if the water supply is limited. However, residual nitrate may move to the deep subsoil and then leach outside the root zone if the water supply exceeds field capacity through either irrigation or rainfall (Sveda et al., 1992). Residual nitrate will leach to a depth of $60 \mathrm{~cm}$ if rainfall or irrigation exceeds $100 \mathrm{~mm}$ under the edaphic and climatic conditions of the North China Plain. Large amounts of residual nitrate in the topsoil may also leach to $120 \mathrm{~cm}$ (the subsoil) after heavy rainfall in late summer or early autumn in some years (Chen et al., 1996), resulting in a substantial change in the nitrate distribution pattern in the soil profile, with the nitrate concentration decreasing in the surface soil and simultaneously increasing in the deeper layers of the soil profile. Large amounts of residual nitrate have been observed to accumulate at various depths in the soil profile under the intensive crop production systems of the North China
Plain (Ju et al., 2004, 2006). We assume that residual nitrate in different layers has a different potential for downward movement according to the rainfall pattern. Nitrate may be transported over relatively long distances in the upper soil layers and over shorter distances in the deeper layers. This leads to a peak of nitrate accumulation at a particular depth in the soil profile under the prevailing sub-humid conditions, with long distance transport to the shallow groundwater occurring only after extremely high water inputs.

The recovery rate of residual nitrate at any particular soil depth by different crops is different owing to differences in root system morphology and root density. Cereal crops usually have deep root systems. For instance, wheat (Triticum aestivum L.) and maize (Zea mays L.) roots may reach a depth of $200 \mathrm{~cm}$. Vegetable crops usually have shallow root systems, especially leafy vegetables such as spinach, the roots of which are distributed mainly in the top $30 \mathrm{~cm}$ of the soil profile. Under these conditions nitrate below a soil depth of $30 \mathrm{~cm}$ may be unavailable to the crop. Nitrate uptake by crops from a particular soil layer is closely related to the root length density in this layer (Schenk et al., 1991; Costa et al., 2000). A higher rooting density in the deep subsoil is therefore the key for full utilization of residual nitrate and prevention of nitrate pollution of the groundwater (Robinson et al., 1994; van Vuuren et al., 1996; Kage, 1997). The recovery rate of residual nitrate also depends on the water consumption of the crops. Crops with higher water consumption can also take up more residual nitrate because large amounts of nitrate can move towards the root systems together with the water (mass flow) under copiously watered crops (Marschner, 1997).

The objective of the present study was to examine the recovery of residual nitrate from different depths in the soil profile by two crops, maize and eggplant, with contrasting root systems and the transport behavior of the nitrate in the soil profile.

\section{Materials and methods}

\subsection{Site description}

The climate on the North China Plain is warm-temperate sub-humid continental monsoon with cold winters and hot summers. The annual precipitation is $500-700 \mathrm{~mm}$, with $60-70 \%$ of the rain falling during summer (JuneSeptember). Residual nitrate in the soil profile is readily leached to the deep subsoil or shallow groundwater during the hot and wet summers (Zhang et al., 1996; Ju et al., 2003). In general, the light textured soils of the alluvial plains at the conjunction of the Yellow, Huai, and Hai rivers are also vulnerable to nitrate leaching. It would therefore be a useful technique to protect groundwater quality in this area by capturing residual nitrate, especially deep soil nitrate, using appropriate crop plants.

The field experiment was conducted from May to September 2002 at Dongbeiwang Experimental Station near Beijing. The research site is located at $39^{\circ}$ $5^{\prime} \mathrm{N}$ and $116^{\circ} 3^{\prime} \mathrm{E}$ at an altitude of $60 \mathrm{~m}$ and the groundwater table is 18$20 \mathrm{~m}$ deep. The experimental period was relatively dry with $445 \mathrm{~mm}$ of precipitation (Fig. 1), which is $80 \%$ of the average precipitation for the period 1952 to 1996 . The experimental soil is a calcareous alluvial soil with a loamy and silty texture (FAO) typical of the region. Selected physicochemical properties of the soil are summarized in Tables 1 and 2. According to the local soil fertility classification in Beijing (Liu et al., 1999) the soil is highly fertile. Cumulative $\mathrm{NO}_{3}^{-}-\mathrm{N}$ in the top $100 \mathrm{~cm}$ of the soil profile before sowing can be as high 
as $215 \mathrm{~kg} \mathrm{~N} \mathrm{ha}^{-1}$, which represents moderate nitrate accumulation in the soil profile of local agricultural fields due to long-term high application rates of $\mathrm{N}$ fertilizers and manures (Ju et al., 2004).

\section{2. ${ }^{15} \mathrm{~N}$ microplots}

The field experiment examined two factors, crop species (main treatment) and ${ }^{15} \mathrm{~N}$ label position (sub-treatment). Maize and eggplant were selected as typical representatives of summer cereal and summer vegetable crops. The three ${ }^{15} \mathrm{~N}$ label positions were soil depths of 15,45 and $75 \mathrm{~cm}$, giving 6 treatments in triplicate and a total of 18 plots arranged in randomized blocks. In addition, control (unlabeled) plots of the two crops were established to correct the ${ }^{15} \mathrm{~N}$-enrichments of labeled plant and soil samples. The area of each ${ }^{15} \mathrm{~N}$ microplot was $1 \times 1 \mathrm{~m}=1 \mathrm{~m}^{2}$. A microplot frame was inserted $35 \mathrm{~cm}$ into the soil with $5 \mathrm{~cm}$ extending aboveground, leaving a 1-m margin between adjacent plots to minimize edge effects.

A ${ }^{15} \mathrm{~N}$ depth placement procedure was used to inject $100 \mathrm{~kg}{ }^{15} \mathrm{~N}$-labeled $\mathrm{N} \mathrm{ha}^{-1}$ into the center of soil zones $0-30,30-60$ and $60-90 \mathrm{~cm}$ at the seedling stage. There were three points of injection for each depth of injection in each plot as shown in Fig. 2. The detailed procedure for labeling at each soil depth was as follows. Three vertical holes were made in the soil to the appropriate depth using a steel auger and a PVC tube was installed in each hole. A syringe was used to inject $24.4 \mathrm{~g}$ of 5.26 atom $\% \mathrm{~K}^{15} \mathrm{NO}_{3}$ (produced by the Institute of Chemical Industry, Shanghai, China) dissolved in $20 \mathrm{ml}$ deionized water through the tubes. The syringes and tubes were then washed by rinsing with $40 \mathrm{ml}$ deionized water. Each hole was backfilled with its original soil and the injection points were labeled at the surface.

Basal fertilizers were applied to each plot by mixing $50 \mathrm{~kg} \mathrm{~N}^{-1}$ as urea, $50 \mathrm{~kg} \mathrm{P}_{2} \mathrm{O}_{5} \mathrm{ha}^{-1}$ as double superphosphate, and $50 \mathrm{~kg} \mathrm{~K}_{2} \mathrm{O} \mathrm{ha}^{-1}$ as potassium sulfate with the top $10 \mathrm{~cm}$ of surface soil before sowing. A further $100 \mathrm{~kg} \mathrm{~N} \mathrm{ha}^{-1}$ as urea was applied to each plot before rainfall as a top dressing at the ten-leaf growth stage (June 23).

Maize variety NongDa 108 and eggplant variety ZhaoQie 1 were grown at a density of 60,000 plants per hectare, i.e. six plants per plot (Fig. 2). Maize was sown on May 2 and eggplant was transplanted on May 5. The ${ }^{15} \mathrm{~N}$ depth placement procedure was carried out on May 13. Irrigation water $(24 \mathrm{~mm})$ was applied on May 27. Eggplant fruits were collected on July 7, July 21, August 1, August 16 and August 29 and oven-dried. The final harvest of maize and eggplant was on September 16.

Time domain reflectometry (TDR) probes were installed in each block of each crop, i.e. three microplots with ${ }^{15} \mathrm{~N}$ label at 15,45 and $75 \mathrm{~cm}$ in each crop were selected to monitor soil water in the top $100 \mathrm{~cm}$ of the soil profile in every 7 days. The average soil water for each crop was calculated from three plots in the crop.

\subsection{Collection of plant and soil samples and measurement}

Six plants were partitioned into grain and straw (maize) or stems, leaves and fruit (eggplant) from each plot at maturity on September 16. All samples were chopped into small pieces, immediately dried for $30 \mathrm{~min}$ at $105{ }^{\circ} \mathrm{C}$, and then dried for $24 \mathrm{~h}$ at $65^{\circ} \mathrm{C}$, weighed and the dry matter yield was calculated. Plant material (including eggplant fruits collected during the experiment) was mixed thoroughly before taking representative samples of each plant component using the quartering procedure, and then ground using a micro hammer

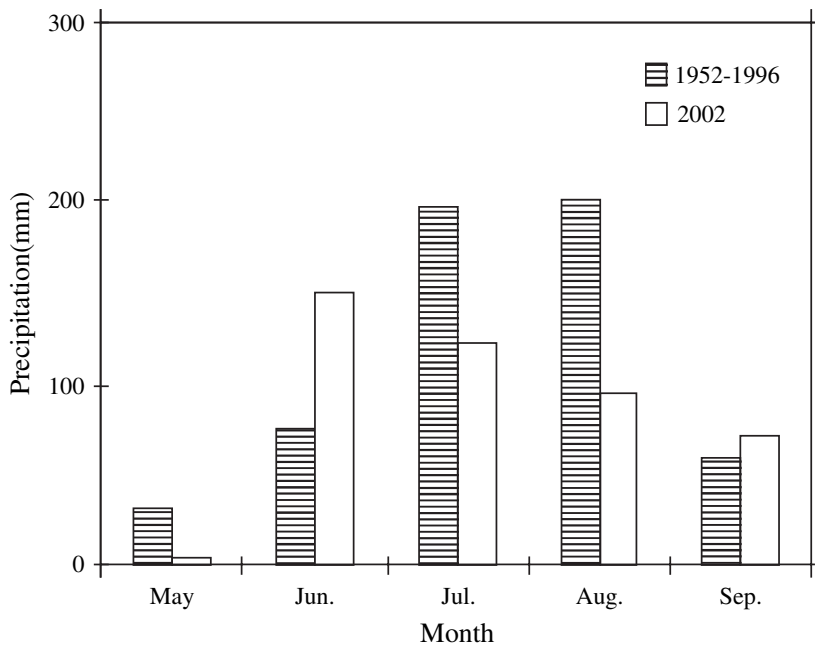

Fig. 1. Comparison between precipitation in the experimental period in 2002 and the average for the same part of the year from 1952 to 1996.

mill to pass a $0.25-\mathrm{mm}$ sieve. All plant samples were analyzed for total $\mathrm{N}$ by the Kjeldahl method and ${ }^{15} \mathrm{~N}$ abundance using a Finnigan Mat model 251 mass spectrometer (Germany) after evaporating the distillate.

Soil samples were collected 5, 10, and $15 \mathrm{~cm}$ from each labeled point (Fig. 2) after harvest to provide information on the possible vertical and horizontal movement of the labeled nitrate. Vertical sampling was done at $10-\mathrm{cm}$ intervals up to $100 \mathrm{~cm}$ depth in the plots labeled at 15 and $45 \mathrm{~cm}$ depths and to $150 \mathrm{~cm}$ in the plots labeled at $75 \mathrm{~cm}$ depth using a steel auger $2 \mathrm{~cm}$ in diameter. Each sample was air-dried and finely ground. Soil total $\mathrm{N}$ was analyzed by the Kjeldahl method after reduction of $\mathrm{NO}_{3}^{-}-\mathrm{N}$ with $5 \% \mathrm{KMnO}_{4}$ and iron powder. ${ }^{15} \mathrm{~N}$ abundance in soil was measured after evaporating the distillate using a Finnigan Mat model 251 mass spectrometer (Germany).

Root samples were taken at the midpoint between two plants at $15-\mathrm{cm}$ depth intervals up to $105 \mathrm{~cm}$ (Fig. 2) with an 8-cm-diameter root auger after crop harvest. Roots were obtained after each soil core was carefully washed on a $0.25-\mathrm{mm}$ sieve. Root length density was determined using the intercept counting techniques described by Tennant (1975).

\subsection{Calculation methods and statistical analysis}

The ${ }^{15} \mathrm{~N}$ enrichment of all plant material was expressed as atom $\%{ }^{15} \mathrm{~N}$ excess. The proportion of the total applied labeled $\mathrm{N}$ recovered by plants was calculated using the formula:

Plant recovery of labeled $\mathrm{N}(\%)$

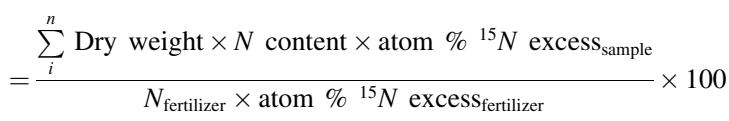

Where $i=$ plant component, $n=2$ in maize (grain and straw) and $n=3$ in eggplant (stem, leaf and fruit) in this study. All of the eggplant fruits collected

Table 1

Selected soil chemical properties at Dongbeiwang experimental station

\begin{tabular}{lllllll}
\hline Soil depth $(\mathrm{cm})$ & $\begin{array}{l}\mathrm{pH} \\
\left(\mathrm{H}_{2} \mathrm{O}\right)\end{array}$ & $\begin{array}{l}\mathrm{OM} \\
\left(\mathrm{g} \mathrm{kg}^{-1}\right)\end{array}$ & $\begin{array}{l}\mathrm{TN} \\
\left(\mathrm{g} \mathrm{kg}^{-1}\right)\end{array}$ & $\begin{array}{l}\text { Olsen-P } \\
\left(\mathrm{mg} \mathrm{kg}^{-1}\right)\end{array}$ & $\begin{array}{l}\mathrm{NH}_{4} \mathrm{OAc}-\mathrm{K}^{2} \\
\left(\mathrm{mg} \mathrm{kg}^{-1}\right)\end{array}$ & $\begin{array}{l}\mathrm{NH}_{4}^{+}-\mathrm{N} \\
\left(\mathrm{kg} \mathrm{ha}^{-1}\right)\end{array}$ \\
\hline $0-20$ & 8.11 & 22.1 & 1.23 & 26.9 & 84.2 & $\begin{array}{l}\mathrm{NO}_{3}^{-}-\mathrm{N} \\
\left(\mathrm{kg} \mathrm{ha}^{-1}\right)\end{array}$ \\
$20-40$ & 8.29 & 20.1 & 1.04 & 17.3 & 63.5 & 13.4 \\
$40-60$ & 8.15 & 10.6 & 0.83 & 8.41 & 42.8 & 13.9 \\
$60-80$ & 8.31 & 7.93 & 0.54 & 3.87 & 20.7 & 11.3 \\
$80-100$ & 8.05 & 6.65 & 0.28 & 2.76 & 15.9 & 12.2 \\
\hline
\end{tabular}

Fresh soil sample was extracted with $0.01 \mathrm{~mol} \mathrm{~L}^{-1} \mathrm{CaCl}_{2}$ to determine the concentrations of $\mathrm{NH}_{4}^{+}-\mathrm{N}$ and $\mathrm{NO}_{3}^{-}-\mathrm{N}$ using a continuous flow analyzer (TRAACS 2000 , Bran and Luebbe, Norderstedt, Germany). The other chemical properties were measured according to the book edited by Sparks (1996). 
Table 2

Selected physical properties of the soil at Dongbeiwang experimental station

\begin{tabular}{|c|c|c|c|c|c|c|c|}
\hline \multirow[t]{2}{*}{ Soil depth $(\mathrm{cm})$} & \multicolumn{3}{|c|}{ Soil texture $(\%)$} & \multirow{2}{*}{$\begin{array}{l}\text { Bulk density } \\
\left(\mathrm{g} \mathrm{cm}^{-3}\right)\end{array}$} & \multirow{2}{*}{$\begin{array}{l}\text { Saturated soil } \\
\text { water content } \\
(\text { w/w \%) }\end{array}$} & \multirow{2}{*}{$\begin{array}{l}\text { Field capacity } \\
(\mathrm{w} / \mathrm{w} \%)\end{array}$} & \multirow{2}{*}{$\begin{array}{l}\text { Wilting point } \\
(\mathrm{w} / \mathrm{w} \%)\end{array}$} \\
\hline & $\begin{array}{l}\text { Sand } \\
(\%)\end{array}$ & $\begin{array}{l}\text { Silt } \\
(\%)\end{array}$ & $\begin{array}{l}\text { Clay } \\
(\%)\end{array}$ & & & & \\
\hline $0-15$ & 27 & 57 & 16 & 1.34 & 40.3 & 25.4 & 7.46 \\
\hline $15-30$ & 27 & 57 & 16 & 1.35 & 31.8 & 20.7 & 5.92 \\
\hline $30-60$ & 22 & 60 & 18 & 1.52 & 25.0 & 19.7 & 6.58 \\
\hline $60-90$ & 31 & 55 & 14 & 1.49 & 24.2 & 19.5 & 4.03 \\
\hline $90-120$ & 20 & 63 & 17 & 1.58 & 28.5 & 20.9 & 6.96 \\
\hline
\end{tabular}

The physical properties were measured according to the book edited by Klute (1996).

during the experiment together with those taken at final harvest were used to calculate the overall ${ }^{15} \mathrm{~N}$ uptake and recovery.

The significance of aboveground biomass, $\mathrm{N}$ uptake and recovery of labeled nitrate by different crops with different depths of soil ${ }^{15} \mathrm{~N}$ labeling was tested by analysis of variance and mean values were compared by least significant difference (LSD) at the 5\% level using the SAS software package (Version 6.12). The distribution of atom $\%{ }^{15} \mathrm{~N}$ excess of total $\mathrm{N}$ in the soil profile, root length density and soil water content of the two crops were compared by $t$-test using Microsoft Excel.

\section{Results}

\subsection{Effects of labeled nitrate on shoot biomass and $N$ uptake}

Total aboveground biomass of neither crop varied significantly with depth of ${ }^{15} \mathrm{~N}$-labeling with nitrate (Table 3). The biomass of maize was significantly higher than that of eggplant and total aboveground $\mathrm{N}$ uptake by both crops showed similar trends to total aboveground biomass (Table 3).

\subsection{Crop recoveries of labeled nitrate at different soil depths}

Mean recoveries of labeled nitrate at depths 15, 45 and $75 \mathrm{~cm}$ by maize were $22.4,13.8$ and $7.8 \%$, respectively,

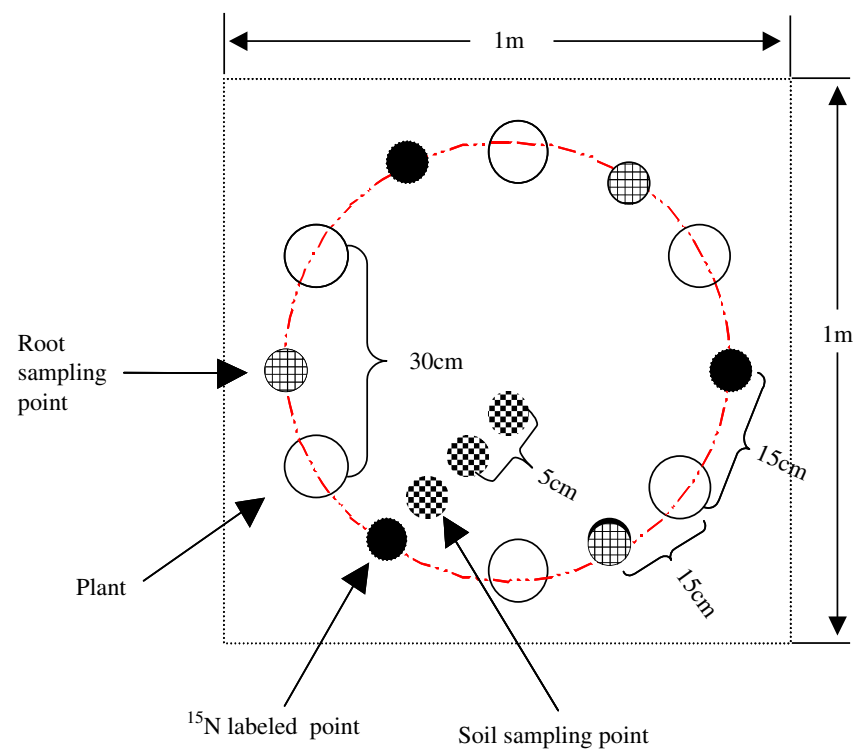

Fig. 2. Schematic diagram showing the structure of the microplots in the field, the positions of the plants, the points of ${ }^{15} \mathrm{~N}$ labeling, and the locations of soil and root sampling. decreasing significantly with increasing depth of labeling. In the case of eggplant, mean recoveries at 15 and $45 \mathrm{~cm}$ were 7.9 and $4.9 \%$ and were not significantly different from each other but were both significantly higher than that of labeled nitrate at a depth of $75 \mathrm{~cm}(2.7 \%)$. Recoveries of labeled nitrate by maize were significantly higher than by eggplant. There were significant interaction effects between crop species and position of labeled nitrate.

\subsection{Vertical movement of labeled nitrate in soil}

${ }^{15} \mathrm{~N}$ abundance of total $\mathrm{N}$ at different soil depths $5 \mathrm{~cm}$ from the labeling positions was determined after crop harvest and the atom $\%{ }^{15} \mathrm{~N}$ excess was calculated on the basis of ${ }^{15} \mathrm{~N}$ natural abundance in the soil of the control plot (Fig. 3). The highest atom $\%{ }^{15} \mathrm{~N}$ excess occurred at $70-$ $80 \mathrm{~cm}$ soil depth for both maize and eggplant when labeled nitrate was injected at $15 \mathrm{~cm}$ depth in the soil profile, indicating downward movement of $\mathrm{NO}_{3}^{-}-\mathrm{N}$. Atom $\%{ }^{15} \mathrm{~N}$ excess of total $\mathrm{N}$ at $20-50 \mathrm{~cm}$ soil depth was slightly lower in the maize than in the eggplant plots, corresponding to the higher recovery of labeled nitrate by maize. The maximum atom $\%{ }^{15} \mathrm{~N}$ excess appeared at $75-85 \mathrm{~cm}$ soil depth for maize and $80-90 \mathrm{~cm}$ for eggplant when labeled nitrate was injected $45 \mathrm{~cm}$ into the soil. The maximum atom $\%$ ${ }^{15} \mathrm{~N}$ excess appeared at $80-90 \mathrm{~cm}$ soil depth for maize and $90-100 \mathrm{~cm}$ for eggplant when labeled nitrate was injected at $75 \mathrm{~cm}$ depth soil and most of the labeled nitrate remained in the soil because of low recovery by the crops from this depth. The amount of residual labeled nitrate was greater in the eggplant plots and moved deeper down the soil profile than in the maize plots.

The vertical movement of the labeled nitrate in maize and eggplant treatments was different when the same amount of water was supplied with $414 \mathrm{~mm}$ of total rainfall and irrigation during the crop growing season. Movement of labeled nitrate was lower in maize treatments compared to eggplant. We used the distance of the maximum atom $\%{ }^{15} \mathrm{~N}$ excess away from the labeled position as an index of movement of labeled nitrate, and calculated the distance of labeled nitrate movement downward derived by $1 \mathrm{~mm}$ of water supply under local soil and climatic conditions (Table 4). However, it is clear that nitrate movement is not related only to total rainfall and irrigation during the crop growing season, but also to the distribution and intensity of rainfall and irrigation. As shown in Fig. 3 
Table 3

Aboveground biomass, $\mathrm{N}$ uptake and recovery of labeled nitrate by different crops with different depths of soil ${ }^{15} \mathrm{~N}$ labeling

\begin{tabular}{|c|c|c|c|c|c|c|}
\hline \multirow[t]{2}{*}{ Label depth $(\mathrm{cm})$} & \multicolumn{2}{|c|}{ Aboveground biomass $\left(\mathrm{g} \mathrm{m}^{-2}\right)$} & \multicolumn{2}{|c|}{ Aboveground $\mathrm{N}$ uptake $\left(\mathrm{g} \mathrm{m}^{-2}\right)$} & \multicolumn{2}{|c|}{ Recovery of labeled nitrate $(\%)$} \\
\hline & Maize & Eggplant & Maize & Eggplant & Maize & Eggplant \\
\hline 15 & $2455.3 \mathrm{a}^{\mathrm{a}}$ & $966.4 \mathrm{a}$ & $29.7 \mathrm{a}$ & $21.6 \mathrm{a}$ & $22.4 \mathrm{a}$ & $7.9 \mathrm{a}$ \\
\hline 45 & $2699.4 \mathrm{a}$ & $1109.1 \mathrm{a}$ & $32.6 \mathrm{a}$ & $24.3 \mathrm{a}$ & $13.8 \mathrm{~b}$ & $4.9 \mathrm{a}$ \\
\hline 75 & $2674.6 \mathrm{a}$ & $1134.4 \mathrm{a}$ & $32.4 \mathrm{a}$ & $25.3 \mathrm{a}$ & $7.8 \mathrm{c}$ & $2.7 \mathrm{~b}$ \\
\hline Mean & 2609.7 & 1069.9 & 31.6 & 23.7 & 14.6 & 5.2 \\
\hline \multicolumn{7}{|l|}{ Significance $^{b}$} \\
\hline Crop species & $* *$ & & $* *$ & & $* *$ & \\
\hline Labeled depth & NS & & NS & & $* *$ & \\
\hline Crop species $\times$ labeled depth & NS & & NS & & $*$ & \\
\hline
\end{tabular}

${ }^{a}$ Within each column, mean values with the same letter are not significantly different by LSD at the $5 \%$ level.

b By analysis of variance; **, $P<0.01$;,$P<0.05$; NS, not significant.

and Table 4, in both crops the deeper the placement of labeled nitrate, the shorter was the distance of vertical movement.

\subsection{Horizontal movement of labeled nitrate in soil}

The ${ }^{15} \mathrm{~N}$ abundance of total $\mathrm{N}$ at different soil depths 10 and $15 \mathrm{~cm}$ away from the labeling position were also determined to investigate horizontal movement of labeled nitrate in the soil. The atom $\%{ }^{15} \mathrm{~N}$ excess in soil 10 and $15 \mathrm{~cm}$ away from the labeling position around the peak layers (i.e. layers of maximum atom $\%{ }^{15} \mathrm{~N}$ excess $5 \mathrm{~cm}$ away from the labeling position, Fig. 3) in both crops exceeded 0 at all three labeled positions, indicating that labeled nitrate moved horizontally more than $15 \mathrm{~cm}$ from the labeled position (data not shown).

\subsection{Relationship between root distribution and recovery of labeled nitrate}

Fig. 4 shows that root length densities of maize were $0.47-$ $1.76 \mathrm{~cm} \mathrm{~cm}^{-3}$ and were significantly higher than those of eggplant $\left(0.10-0.70 \mathrm{~cm} \mathrm{~cm}^{-3}\right)$ throughout the soil profile to a depth of $105 \mathrm{~cm}$. This trend corresponded to the higher $\mathrm{N}$ uptake and higher recovery of labeled nitrate by maize compared with eggplant. Root length density decreased with increasing soil depth, leading to a decrease in the recovery of labeled nitrate from the subsoil. Root length density $(x)$ in soil layers where the ${ }^{15} \mathrm{~N}$ was injected was significantly and positively correlated with the $\%$ recovery of the injected ${ }^{15} \mathrm{~N}(y)$ in both crops (maize: $y=19.12 x-8.07, r=0.920, P<0.01$; eggplant: $y=14.00$ $x-1.09, r=0.899, P<0.01)$. The steeper slope of the regression line for maize reflected the stronger increase in $\%$ recovery with increasing root length density compared to eggplant.

\subsection{Dynamics of soil water at different soil depths over the crop growing season}

Two clear increases in soil water were detected at different soil depths down to $100 \mathrm{~cm}$ during the crop growing season under the same rainfall and irrigation inputs to both crop species. The first increase appeared 40-55 days after sowing and the second after 70-110 days (Fig. 5). The water content throughout the soil profile remained below field capacity during most of the growing season (Table 2), indicating that any soil water movement occurred under non-saturated conditions or through soil interstitial spaces. The highly soluble labeled nitrate is likely to have moved with this flow of water. The water content in the surface $20 \mathrm{~cm}$ of the soil profile showed no significant difference between the two crops throughout the
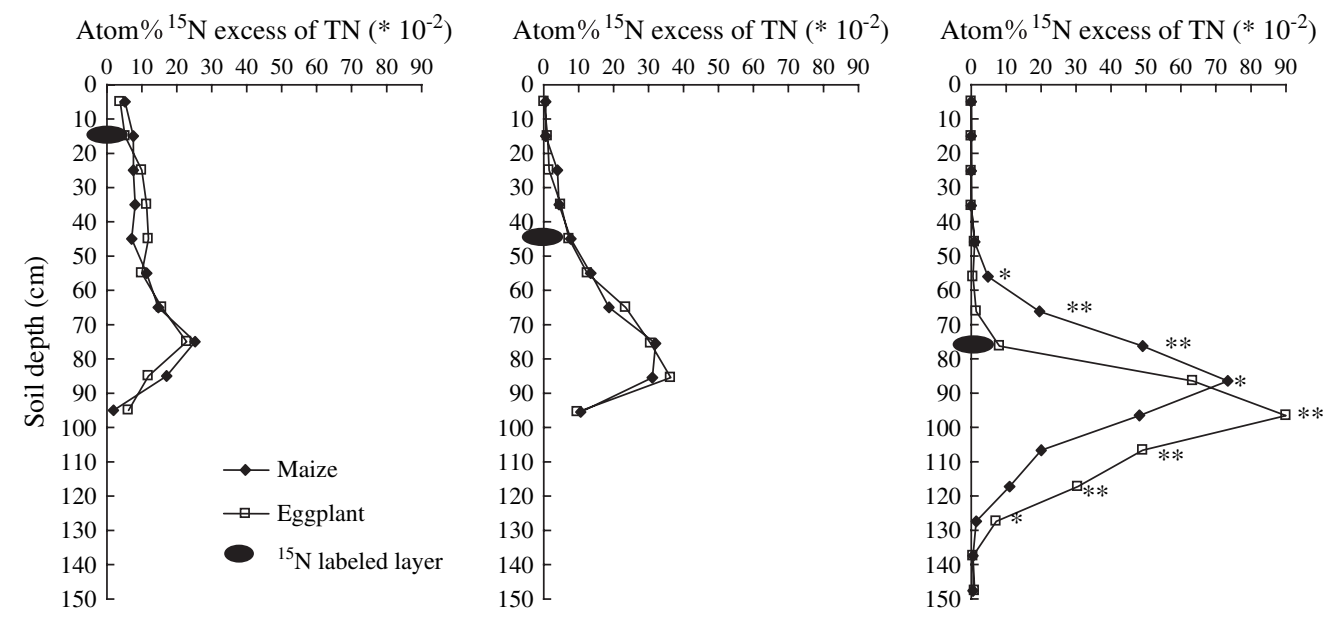

Fig. 3. Distribution of atom $\%{ }^{15} \mathrm{~N}$ excess of total $\mathrm{N}$ in the soil profile $5 \mathrm{~cm}$ from different labeling points after harvest of the two crops $(*$, significant difference at the $5 \%$ level; **, significant difference at the $1 \%$ level (both by $t$-test)). 
Table 4

Transport of labeled nitrate in the soil profile

\begin{tabular}{|c|c|c|c|c|c|c|}
\hline \multirow[t]{2}{*}{ Labeled depth $(\mathrm{cm})$} & \multicolumn{2}{|c|}{ Atom $\%{ }^{15} \mathrm{~N}$ excess total $\mathrm{N}(\mathrm{cm})$} & \multicolumn{2}{|c|}{$\begin{array}{l}\text { Distance of downward movement of } \\
\text { labeled } \mathrm{N}(\mathrm{cm})\end{array}$} & \multicolumn{2}{|c|}{$\begin{array}{l}\text { Distance of downward movement of labeled } \\
\mathrm{N} \text { from } 1 \mathrm{~mm} \text { precipitation or irrigation }(\mathrm{cm})\end{array}$} \\
\hline & Maize & Eggplant & Maize & Eggplant & Maize & Eggplant \\
\hline 15 & $70-80$ & $70-80$ & $60 \mathrm{a}^{\mathrm{a}}$ & $60 \mathrm{a}$ & $0.145 \mathrm{a}$ & $0.145 \mathrm{a}$ \\
\hline 45 & $75-85$ & $80-90$ & $35 \mathrm{a}$ & $40 \mathrm{a}$ & $0.084 \mathrm{a}$ & $0.100 \mathrm{a}$ \\
\hline 75 & $80-90$ & $90-100$ & $10 \mathrm{~b}$ & $20 \mathrm{a}$ & $0.024 \mathrm{~b}$ & $0.048 \mathrm{a}$ \\
\hline
\end{tabular}

${ }^{\mathrm{a}}$ Within each row, mean values with the same letter between two crops are not significantly different by $t$-test at the $5 \%$ level.

growing season. The water content at $20-40 \mathrm{~cm}$ depth showed no differences at other times except for around 85 days after sowing when it was significantly higher in eggplant than in maize plots. The water content in the $40-100 \mathrm{~cm}$ depth zone did not vary significantly over the first 85 days and was significantly higher in eggplant than in maize plots after 85 days. Maize had a higher water requirement and absorbed subsoil water 85 days after sowing, and this prevented the downward movement of subsoil water and resulted in shorter distance movement of labeled nitrate in the maize plots compared to the eggplant plots.

\section{Discussion}

Edaphic and climatic conditions on the North China Plain are generally favorable for mineralization and nitrification (Richter and Roelcke, 2000; Liu et al., 2003; Ju et al., 2004). These conditions, combined with the high $\mathrm{N}$ surpluses arising from excessive fertilizer applications, lead to accumulation of nitrate at various soil depths. The amount of residual nitrate in the top $100 \mathrm{~cm}$ of the soil profile in the experimental field before sowing was $215 \mathrm{~kg} \mathrm{~N} \mathrm{ha}^{-1}$. This, together with $100 \mathrm{~kg} \mathrm{~N} \mathrm{ha}^{-1}$ of labeled nitrate, gives a total of $315 \mathrm{~kg} \mathrm{ha}^{-1}$ nitrate-N, which represents high nitrate accumulation in the soil profile typical of local wheat-maize rotation fields (Ju et al., 2004, 2006). The recoveries of labeled nitrate by the two crops $(2.7-22.4 \%$, depending on crop species and depth of labeled nitrate

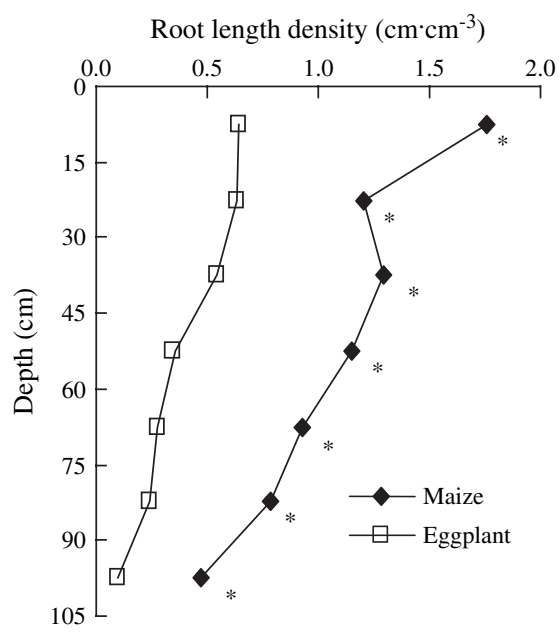

Fig. 4. Root distributions of maize and eggplant at different soil depths after harvest (*, significant difference at the $5 \%$ level by $t$-test). placement) in our experiment were likely to be representative of local farming conditions using typical fertilizer application rates $\left(150 \mathrm{~kg} \mathrm{~N} \mathrm{ha}^{-1}\right.$ applied to the top soil). Labeled nitrate placed at different soil depths was taken up by the crops or transported down the soil profile in a similar fashion to indigenous residual nitrate at different soil depths as indicated by the distribution of nitrate measured after crop harvest (data not shown). Our results indicate that the recovery of labeled nitrate from deep down the soil profile was quite low, emphasizing the very high potential for large losses of residual nitrate to the subsoil in intensive crop production systems in the region. Due to the uneven horizontal distribution of labeled ${ }^{15} \mathrm{~N}$ in the soil after harvest, we only investigated the trends of changes in labeled ${ }^{15} \mathrm{~N}$ by taking soil samples $5 \mathrm{~cm}$ away from the labeling positions and we cannot calculate the percentage recovery of the labeled ${ }^{15} \mathrm{~N}$ in the soil. Because the crop recoveries of labeled nitrate placed at shallow depths was much higher than of labeled nitrate placed at greater depths, recoveries of labeled nitrate in the soil would be expected to show the opposite trend.

Crop species significantly affected the recovery of residual nitrate at different soil depths. Nitrate leaching can be substantially reduced by crops with high N uptake ability (Steenvoorden, 1989). Residual nitrate in the soil profile showed a significant negative relationship with the amount of $\mathrm{N}$ uptake by different maize varieties (Wiesler and Horst, 1992, 1993). Maize has a large fibrous root system that can usually extend to a soil depth of $140-150 \mathrm{~cm}$ and sometimes to $200 \mathrm{~cm}$, but over $80 \%$ of the roots are distributed in the top $30 \mathrm{~cm}$ (Anonymous, 1983). In contrast, eggplant has a root system in which the main and lateral roots are more clearly defined and can extend to $130-170 \mathrm{~cm}$ depth, but most of the roots are distributed within the top $25 \mathrm{~cm}$ of the cultivated layer and they display early lignification (Zhou and Li, 2002). The root length density of maize is usually higher than that of eggplant because of its strong fibrous roots. Wiesler and Horst (1994) showed that the degree of exhaustion of nitrate in the subsoil increased with increasing crop rooting density in the deeper horizons. The results of our experiment indicate that the root length density of maize was significantly higher than that of eggplant in the top $105 \mathrm{~cm}$ of the soil profile (Fig. 4), leading to higher uptake of $\mathrm{N}$ and recovery of labeled nitrate at different soil depths by maize than by eggplant.

The higher water consumption of maize may also have contributed to the higher uptake and recovery of labeled nitrate at any given soil depth by maize compared to eggplant. Due to differences in albedo, crop height, aerodynamic properties, 

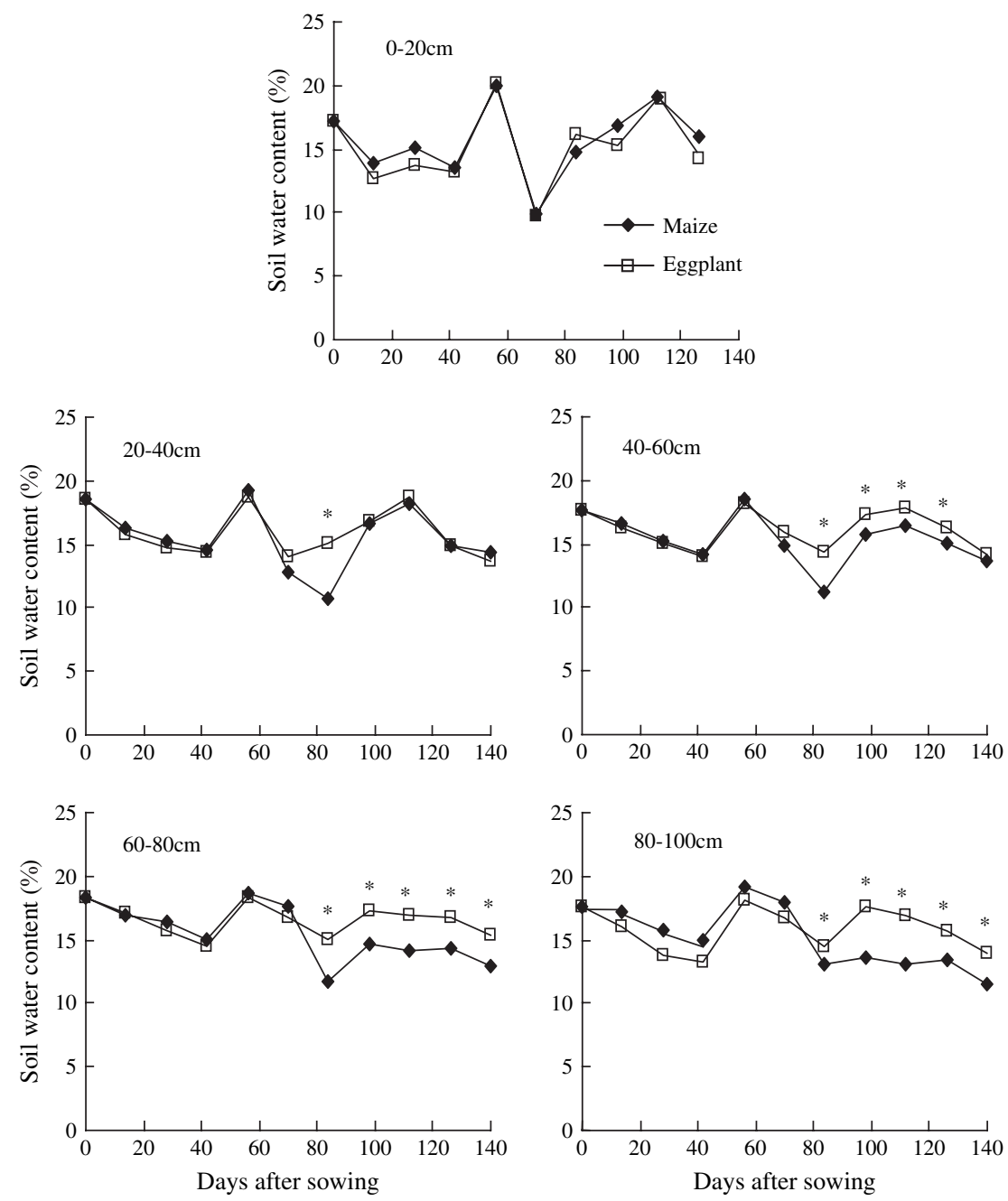

Fig. 5. Dynamics of soil water content at different soil depths during the growing season of maize and eggplant $(*$, significant difference at the $5 \%$ level by $t$-test).

and leaf and stomatal properties, the crop coefficient $(\mathrm{Kc})$ of maize is much higher than that of eggplant, leading to higher evapotranspiration from fully grown, copiously watered maize compare with eggplant (Allen et al., 1998). The higher water consumption by maize than by eggplant was also reflected by the lower soil water content at $40-100 \mathrm{~cm}$ depth 85 days after sowing (Fig. 5). The labeled nitrate was presumably taken up during transpiration and the higher water consumption by maize may thus help to account for the large recovery of labeled nitrate in maize.

Within each crop, the question arises why the peak of the labeled nitrate appeared at similar soil depth after harvest although the labeled nitrate was originally injected at different depths and why the deeper the ${ }^{15} \mathrm{~N}$-labeled nitrate placement, the smaller the distance of downward movement of the ${ }^{15} \mathrm{~N}$-labeled nitrate. This may be explained by soil water movement derived from rainfall during the crop growing season (Fig. 5). Water flow from rainfall may only have penetrated to a certain depth of soil. Labeled nitrate may have moved downward with the soil water instead of moving to greater depths. This would also explain the high cumulative nitrate peak that usually appears deep in the soil profile after excessive application of $\mathrm{N}$ fertilizer under the prevailing sub-humid climatic conditions with the onset of precipitation of 500-700 cm (Guo et al., 2003a; Yang et al., 2001; Ju et al., 2004). This cumulative nitrate usually resides in the soil for a long time (Richter and Roelcke, 2000; Guo et al., 2003b) unless there is an extremely high water supply when it may leach to the shallow groundwater. This extremely high rainfall has been observed to occur in some years on the North China Plain. For example, $103 \mathrm{~mm}$ of rain fell on June 301998 and $76 \mathrm{~mm}$ on July 292004 in the Beijing area.

The horizontal movement of labeled nitrate in the soil in excess of $15 \mathrm{~cm}$ in our field experiment agrees with results obtained from a clay soil in Kenya (Gathumbi et al., 2003) in which labeled nitrate diffused to the whole layer of the soil from the labeling point and the crop took up labeled nitrate from whole labeled soil layer.

\section{Conclusions}

Crops with deep rooting systems and high water consumption may have higher recoveries of residual nitrate than crops with shallow rooting systems and low water consumption. The 
low recoveries of residual nitrate located in the deep subsoil by both crops illustrate the great potential losses of nitrate to pollute the shallow groundwater under current farming practices on the North China Plain. To mitigate this environmental risk, techniques such as the Nmin method for $\mathrm{N}$ fertilizer recommendation should be adopted by extension workers to prevent progressive accumulation of nitrate in the soil profile, especially in the deep subsoil after harvest. A trend of nitrate movement in which the deeper the nitrate is located in the soil profile the shorter the distance it will move downward may explain how the peak of residual nitrate was clearly discernible in the prevailing sub-humid soil and climatic conditions. This residual nitrate may reside in the soil for extended periods until extremely large rainfall events occur or large amounts of water are supplied by excessive irrigation, resulting in the leaching of nitrate to the shallow groundwater. Crops with deeper root systems and high water consumption may therefore be grown to utilize the high residual nitrate in the soil. Careful management of the water supply for field crops is also required to minimize or control the downward movement of residual nitrate in the soil profile.

\section{Acknowledgments}

We acknowledge generous financial support from the National Natural Science Foundation of China (grants 40571072, 30390081 and 30270787), the Program for Changjiang Scholars and Innovative Research Team in University (IRT0511).

\section{References}

Allen, G.R., Pereira, S.L., Raes, D., Smith, M., 1998. Crop Evapotranspiration (Guidelines for Computing Crop Water Requirements). FAO Irrigation and Drainage Paper No. 56. FAO, Rome, Italy, 300 pp.

Angle, J.S., Gross, C.M., Hill, R.L., Mclntosh, M.S., 1993. Soil nitrate concentrations under corn as affected by tillage, manure, and fertilizer applications. Journal of Environmental Quality 22, 141-147.

Anonymous, 1983. Chinese maize planting science. Agricultural Academy of Shandong Province. In: Shanghai Science and Technology Publishers, Shanghai, pp. 27-39 (in Chinese).

Aulakh, M.S., Doran, J.W., Mosier, A.R., 1992. Soil denitrification: significance, measurement, and effects of management. Advances in Soil Science $18,1-57$.

Boswell, F.C., Anderson, O.E., 1964. Nitrogen movement in undisturbed profiles of fallowed soils. Agronomy Journal 56, 278-281.

Chen, X.P., 2003. Optimization of the $\mathrm{N}$ fertilizer management of a winter wheat/summer maize rotation system on the North China Plain. PhD Dissertation, University of Hohenheim, Stuttgart, Germany, 123 pp.

Chen, Z.M., Yuan, F.M., Yao, Z.H., Zhu, C.S., Fu, G.M., Song, Y.L., Li, X.P., 1996. Translocation and leaching of the nitrate in alluvial soils in Beijing area. In: Chen, Z.M. (Ed.), Nitrogen, Yield and Environment. Chinese Agricultural Publishers, Beijing, pp. 1-3 (in Chinese with English summary).

Costa, J.M., Bollero, G.A., Coale, F.J., 2000. Early season nitrate accumulation in winter wheat. Journal of Plant Nutrition 23, 773-783.

Gathumbi, S.M., Cadisch, G., Buresh, R.J., Giller, K.E., 2003. Subsoil nitrogen capture in mixed legume stands as assessed by deep nitrogen- 15 placement. Soil Science Society of America Journal 67, 573-582.

Glendining, M.J., Poulton, P.R., Powlson, D.S., MacDonald, A.J., Jenkinson, D.S., 2001. Availability of the residual nitrogen from a single application of ${ }^{15} \mathrm{~N}$-labelled fertilizer to subsequent crops in a long-term continuous barley experiment. Plant and Soil 233, 231-239.
Guo, S.L., Wu, J.S., Hao, M.D., Dang, T.H., 2003a. Effects of long-term fertilization on cumulative $\mathrm{NO}_{3}^{-}-\mathrm{N}$ in deep subsoil and the distribution of soil water in soil profile. Chinese Journal of Applied Ecology 14, 75-78 (in Chinese with English summary).

Guo, S.L., Zhang, W.J., Dang, T.H., Wu, J.S., Hao, M.D., 2003b. Accumulation of $\mathrm{NO}_{3}^{-}-\mathrm{N}$ in deep layers and its affecting factors in dry farmland. Advances in Earth Science 18, 584-591 (in Chinese with English summary).

Huang, Y., Rickert, D.H., Kephart, K.D., 1996. Recovery of deep-point injected soil nitrogen-15 by switchgrass, alfalfa, ineffective alfalfa, and corn. Journal of Environmental Quality 25, 1394-1400.

Jensen, L.S., Christensen, L., Mueller, T., Nielsen, N.E., 1997. Turnover of residual ${ }^{15} \mathrm{~N}$-labelled fertilizer $\mathrm{N}$ in soil following harvest of oilseed rape (Brassica napus L.). Plant and Soil 190, 193-202.

Ju, X.T., Liu, X.J., Zhang, F.S., 2003. Accumulation and movement of $\mathrm{NO}_{3}^{-}-\mathrm{N}$ in soil profile in winter wheat-summer maize rotation system. Acta Pedologica Sinica 40, 538-546 (in Chinese with English summary).

Ju, X.T., Liu, X.J., Zhang, F.S., Roelcke, M., 2004. Nitrogen fertilization, soil nitrate accumulation, and policy recommendations in several agricultural regions of China. Ambio 33, 300-305.

Ju, X.T., Kou, C.L., Zhang, F.S., Christie, P., 2006. Nitrogen balance and groundwater nitrate contamination: comparison among three intensive cropping systems on the North China Plain. Environmental Pollution 143, 117-125.

Kage, H., 1997. Is low rooting density of faba beans a cause of high residual nitrate content of soil at harvest? Plant and Soil 190, 47-56.

Klute, A. (Ed.), 1996. Methods of Soil Analysis. Part 1: Physical and Mineralogical Methods. SSSA and ASA, Madison, WI, SSSA Book Series: No. 5, second ed. $1188 \mathrm{pp}$.

Liu, B.C., Sun, M.D., Wu, J., 1999. Soil fertility and fertilization in Beijing area. Beijing Agricultural Science 17, 30-34 (in Chinese with English summary).

Liu, X.J., Ju, X.T., Zhang, F.S., Pan, J.R., Christie, P., 2003. Nitrogen dynamics and budgets in a winter wheat-maize cropping system in the North China Plain. Field Crops Research 83, 111-124.

Marschner, H., 1997. Mineral Nutrition of Higher Plants, second ed. Academic Press, London, $889 \mathrm{pp}$

Menezes, R.S.C., Gascho, G.J., Hanna, W.W., Cabrera, M.L., Hook, J.E., 1997. Subsoil nitrate uptake by grain pearl millet. Agronomy Journal 89, 189-194.

Recous, S., Mary, B., Faurie, G., 1990. Microbial immobilization of ammonium and nitrate in cultivated soils. Soil Biology and Biochemistry 22, 913-922.

Richter, J., Roelcke, M., 2000. The N-cycle as determined by intensive agriculture: examples from central Europe and China. Nutrient Cycling in Agroecosystems 57, 33-46.

Robinson, D., Linehan, D.J., Gordon, D.C., 1994. Capture of nitrate from soil by wheat in relation to root length, nitrogen inflow and availability. New Phytologist 128, 297-306.

Roth, G.W., Fox, R.H., 1990. Soil nitrate accumulations following nitrogen fertilized corn in Pennsylvania. Journal of Environmental Quality 19, 243-248.

Rowe, E.C., van Noordwijk, M., Suprayogo, D., Hairayah, K., Giller, K.E., Cadisch, G., 2001. Root distributions partially explain ${ }^{15} \mathrm{~N}$ uptake patterns in Gliricidia and Peltophorum hedgerow intercropping systems. Plant and Soil 235, 167-179.

Schenk, M., Heins, B., Steingrobe, B., 1991. The significance of root development of spinach and kohlrabi for $\mathrm{N}$ fertilization. Plant and Soil 135, 197-203.

Sparks, D.L. (Ed.), 1996. Methods of Soil Analysis. Part 3: Chemical Methods. SSSA and ASA, Madison, WI, SSSA Book Series: No. 5. 1390 pp.

Steenvoorden, J.H.A.M., 1989. Agricultural practices to reduce nitrogen losses via leaching and surface runoff. In: Germon, J.C. (Ed.), Management Systems to Reduce Impact of Nitrate. Elsevier, London, pp. 72-84.

Strong, W.M., Dalal, R.C., Weston, E.J., Cooper, J.E., Lehane, K.J., King, A.J., 1996. Nitrogen fertiliser residues for wheat cropping in subtropical Australia. Australian Journal of Agricultural Research 47, 695703. 
Sveda, R., Rechcigl, J.E., Nkedikizza, P., 1992. Evaluation of various nitrogen sources and rates on nitrogen movement, Pensacola bahiagrass production, and water quality. Communications in Soil Science and Plant Analysis 23, $2451-2478$.

Tennant, D., 1975. Test of a modified line intersect method of estimating root length. Journal of Ecology 63, 995-1001.

van Vuuren, M.M.I., Robinson, D., Griffiths, B.S., 1996. Nutrient inflow and root proliferation during the exploitation of a temporally and spatially discrete source of nitrogen in soil. Plant and Soil 178, 185-192.

Wiesler, F., Horst, W.J., 1992. Differences between maize cultivars in yield formation, nitrogen uptake and associated depletion of soil nitrate. Journal of Agronomy and Crop Science 168, 226-237.

Wiesler, F., Horst, W.J., 1993. Differences among maize cultivars in the utilization of soil nitrate and the related losses of nitrate through leaching. Plant and Soil 151, 193-203.
Wiesler, F., Horst, W.J., 1994. Root growth and nitrate utilization of maize cultivars under field conditions. Plant and Soil 163, 267-277.

Yang, X.Y., Zhang, S.L., Yuan, X.M., Tong, Y.A., 2001. Effects of long-term fertilization on distribution, accumulation and translocation of nitrate in loess soils. Plant Nutrition and Fertilization Science 7, 134-138 (in Chinese with English summary).

Zhang, W.L., Tian, Z.X., Zhang, N., Li, X.Q., 1996. Nitrate pollution of groundwater in northern China. Agriculture. Ecosystems and Environment 59, 223-231.

Zhou, B.L., Li, Y.Y. (Eds.), 2002. High Yield and Quality Planting of the Eggplant: Principles and Technology. Chinese Agricultural Publishers, Beijing, pp. 7-9 (in Chinese).

Zhu, Z.L., 1997. Fate and management of fertilizer nitrogen in agroecosystems. In: Zhu, Z.L., Wen, Q.X., Freney, J.R. (Eds.), Nitrogen in Soils of China. Kluwer, Dordrecht, the Netherlands, pp. 239-279. 